\title{
Replacement of bicuspid aortic valve with sutureless bioprosthesis: A word of caution here
}

\author{
Michel Carrier, MD
}

\author{
From the Department of Surgery, Montreal Heart Institute, Montréal, Québec, Canada. \\ Disclosures: Author has nothing to disclose with regard to commercial support. \\ Received for publication Feb 11, 2018; accepted for publication Feb 15, 2018; available ahead of print March 13, \\ 2018. \\ Address for reprints: Michel Carrier, MD, 5000 Belanger E, Montreal, Québec H1T 1C8, Canada (E-mail: michel \\ carrier@icm-mhi.org). \\ J Thorac Cardiovasc Surg 2018;156:e91 \\ $0022-5223 / \$ 36.00$ \\ Copyright (C) 2018 by The American Association for Thoracic Surgery \\ https://doi.org/10.1016/j.jtcvs.2018.02.043
}

Aortic valve replacement with sutureless and rapiddeployment bioprostheses has gained in popularity because of the technical ease of implantation through smaller surgical incisions, referred to as "minimally invasive approaches." 1 Not only do these sutureless prostheses decrease operating room time, they also allow the performance of an operation that results in less trauma to the chest wall, less postoperative pain, and a shorter recovery time. ${ }^{1}$

In this issue of the Journal, Chiariello and colleagues ${ }^{2}$ report the case of a patient who underwent bicuspid aortic valve replacement with a sutureless prosthesis and showed dislocation of the prosthesis 2 years after implantation. At initial inspection, the bicuspid aortic valve appeared to be a type 1. A size XL Perceval sutureless prosthesis (LivaNova PLC, London, United Kingdom) was implanted after placement of the 3 guiding sutures at $120^{\circ}$ of separation through the annulus. Echocardiographic evaluation of the prosthesis appeared normal throughout the first year after implantation. Only 14 months after that did aortic regurgitation appear. At reoperation, the prosthesis was dislocated, with an upstream and posterior displacement into the noncoronary cusp.

Although, it has previously been demonstrated that sutureless aortic valve replacement can be performed safely in patients with bicuspid valves, ${ }^{3}$ this case report of Chiariello and colleagues ${ }^{2}$ suggests that the prosthesis could remain unstable and dislocate several months after implantation. We must remember that the Perceval sutureless bioprosthesis was originally designed for a normal annulus, albeit decalcified in part, with appropriate sinotubular junction and normal sinuses of Valsava. ${ }^{4}$ Positioning the 3 nadir guiding sutures at $120^{\circ}$ in asymmetric cusps and redirecting radial pressure of the sutureless prosthesis on the annulus

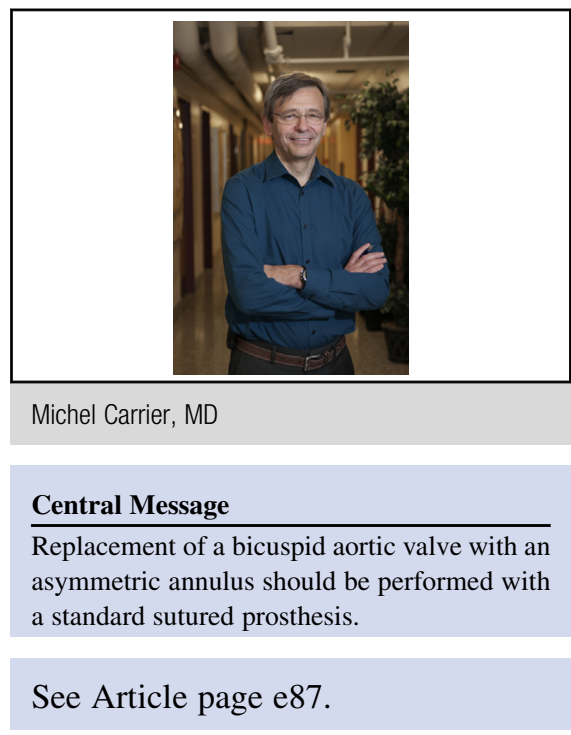

may be difficult in some cases. Moreover, Glauber and associates ${ }^{5}$ have suggested that commissural plication is often required to restore proper shape of the annulus.

In my mind, the take-home message is that replacement of bicuspid aortic valve with asymmetric annulus should be performed with standard sutured prostheses, with automatic knot-tying devices and shafted instruments used if needed. Currently, sutureless and rapid-deployment prosthesis must be reserved for patients with circular annulus and symmetric sinuses.

\section{References}

1. Laufer G, Wiedemann D, Chitwood WR Jr. Rapid-deployment valves: finally the fog is lifting-benefits beyond crossclamp and bypass times. J Thorac Cardiovasc Surg. 2017; 154:1527-31

2. Chiariello GA, Villa E, Messina A, Troise G. Dislocation of a sutureless prosthesis after type I bicuspid aortic valve replacement. J Thorac Cardiovasc Surg. 2018; 156:e87-9.

3. Nguyen A, Fortin W, Mazine A, Bouchard D, Carrier M, El Hamamsy I, et al. Sutureless aortic valve replacement in patients who have bicuspid aortic valve. $J$ Thorac Cardiovasc Surg. 2015;150:851-7.

4. Folliguet TA, Laborde F, Zannis K, Ghorayeb G, Haverich A, Shrestha M. Sutureless perceval aortic valve replacement: results of two European centers. Ann Thorac Surg. 2012;93:1483-8.

5. Glauber M, Ferrarini M, Lio A, Miceli A. Dealing with a stenotic bicuspid aortic valve: is this still an off-label procedure for a sutureless valve? J Thorac Cardiovasc Surg. 2015;150:858-9. 